\title{
Evaluation of Physical, Spatial and Demographic Expansions in Ilam City from 1956 to 2016
}

\author{
Karamreza Mirzaei \\ Social Sciences Department, College of Basic Education, University of Zakho - Kurdistan Region of Iraq; mirzai.kr@gmail.com; \\ karam.merza@staff.uoz.uoz.krd
}

\begin{abstract}
The physical and spatial expansion of cities, which often taken place without planning, caused numerous environmental, health, economic and social problems. This study investigates the physical, spatial, and demographic development and expansion of Ilam city in Iran for over 60 years. To achieve these goals, library studies, data analysis, and field studies were applied. The process of development in Ilam and its demographic changes from 1956 to 2016 has been presented, and then, the spatial-physical expansion of the city is evaluated. The results showed that several factors had impacted the physical development and expansion of Ilam. The highest growth was observed between 1976 and 1986. Also, the development of the city has been more horizontal. The study results show the correlation, intensity, extension, and mechanism of conversion and land-use change in Ilam city and embody its spatial-physical expansion.
\end{abstract}

Keywords: Evaluation, Spatial-Physical Expansion, Ilam

Received: $x x x /$ Accepted: $x x x /$ Online: $x x x$

\section{Introduction}

Today, one of the problems and challenges of urban planning is the physical and unplanned expansion of cities, especially in developing countries. The physical and spatial development of cities results from population growth, economic and industrial growth, and rural-urban migration, which caused numerous environmental, health, economic and social problems (Pourmohammadi and Zamani 2007). Destroying green spaces, gardens, and agricultural lands, intense changes of land use to impermeable levels, air and water pollution, reducing the sound quality, and environmental destruction are among the most obvious and important environmental problems of physical development and expansion of cities (Muhammed at al.2020; Kourosh Niya at al.2029).

Numerous factors such as high inflation in housing price, marginalization, illegal segregation of land, inability to provide the same urban services, construction in environmentally steep and hazardous areas, destruction of agricultural land, and integration of rural settlements in the physical organ of cities have been influential in the rapid process of spatial-physical expansion of cities, followed by positive and negative feedbacks in most centers of the province and major cities of Iran (Pourmohammadi and Zamani 2007; Roostayi at al.2016). Undoubtedly, a major part of the unfavorable expansion of cities is due to inefficient urban management and lack of balance of supply and rational demand in the land market, as well as lack of proper knowledge of processes, flows, socio-ecological sequences (Lei at al., 2021). Spatial-physical expansion is not the same in all aspects quantitatively and qualitatively, and it has different conditions in different areas depending on the accumulation and concentration of capitals and the presence of law and the application of urban planning regulations, so these are the main points in the spatial-physical expansion of cities in many developing countries (Hu at al., 2008). 
Many studies have evaluated cities' spatial, physical, and demographic expansion in Iran and other countries in different periods. In many of those studies, remote sensing and GIS techniques have provided up-to-date satellite images with appropriate spatial and spectral accuracy. Studies such as Pourmohammadi et al. (Pourmohammadi \& Zamani,2007). (Hu et al., 2008; Bagan and Yamagata 2012; Karimi et al., 2018; Kouroshnya et al.2020; Karimi et al. 2020; Mustafa, 2020; Alawamy, et al 2020; and Effati et al. 2020) evaluated the changes in land use - land cover and demography in the cities and regional scale and the impact on the microclimate of city and environment were investigated.

Ilam city is one of the ancient cities of Iran, which has a historical settlement dating. This city became part of Kermanshah Province in 1930 in the national divisions, and it was upgraded to the center of Ilam province in 1974. At present, the physical shape of Ilam is developing like an asymmetric triangle, following the previous expansions and according to the construction of side roads, but there are still barren lands and hills between the dense and even semi-dense texture of Ilam city. In the east, the city has naturally lost its ability to expand due to the heights. Therefore, the city has expanded to the north, southwest, west. The city development plans have also provided development in the western side of Ilam. Ilam has had a rapid and unplanned development in recent decades; therefore, its population had significantly increased from 32476 thousand in 1976 to 194030 inhabitants in 2016. This study investigates the physical-spatial and demographic expansion and development of Ilam city during the last 60 years, namely from 1956 to 2016. The following case study, methods, results, discussion, and conclusions are provided in detail.

\section{Materials and Methods}

\subsection{Study Area}

Ilam city, the capital of Ilam province, with a latitude of $32^{\circ} 38^{\prime}$ and a longitude of $46^{\circ} 26^{\prime}$ is located in the west of Iran. Figure 1 shows the location of Ilam city and Ilam province. The province is limited to Kermanshah province from the north, Lorestan province from the east, Khuzestan province, Iraq from the south and west. It has a $425 \mathrm{~km}$ common border with Iraq. According to the last census of 2016, the city's population is 194,030 inhabitants within 53,581 households. Ilam city has a temperate mountainous climate with an average annual rainfall of about $620 \mathrm{~mm}$, and its average temperature varies from -13 to $42^{\circ} \mathrm{C}$.

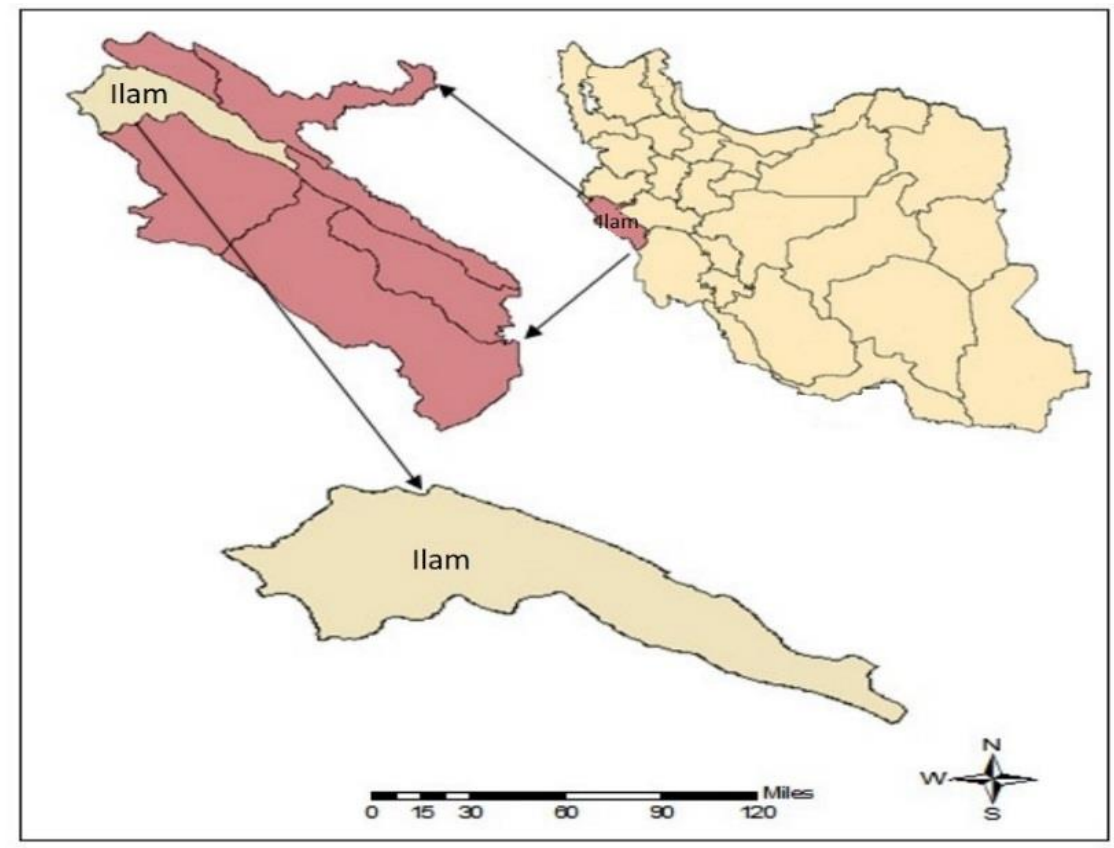

Figure 1. The location of case study (Ilam city). 


\subsection{Method}

In this research, two general methods were used, which will be briefly explained below. Initially, library studies were conducted, including collecting data and information from library resources, several organizations and departments, and valid national sites. In the library survey, statistics related to the population during the study period and the process of changes, the statistics needed to study population density in districts and areas of Ilam city, and the stages of spatial and physical development and expansion of Ilam were collected and then analyzed. Then, field checks were conducted to collect information, and the dispersion of various urban uses, including agricultural uses, gardens, man-made, etc. were investigated. Also, ArcGIS software was used to prepare the required maps.

\section{Result and Discussion}

\subsection{Demographic Charactristics}

The first official statistics of the population is for 1956, in which the number of 1366 households, including 8346 people, was counted, and it had reached 15493 in 1966. In 1976, the population of Ilam included 32476 inhabitants. During the ten years from 1966 to 1976, the annual population growth has increased and reached 7.4 percent. Up to two-thirds of this population was related to immigration of Ilam city in the mentioned years, which is the result of establishing the governorate of Ilam to the center of Ilam city and later transforming and promoting Ilam to the province (Musa Kazemi, 2007). In 1986, increasing the population growth of this city was observed up to $10.65 \%$. In addition to natural growth, this increase was the result of imposed war migrations because villagers and residents of border towns were exposed to war fires and attacks during the war were forced to seek refuge in other cities. After the end of the war in 1988, measures were taken to rebuild and return the immigrants from the imposed war. The report of the 1991 census showed that the population of Ilam in that year was equal to 116,428 people, which shows that the increasing annual population growth has decreased compared to previous periods. It has reached 36\% from 1986 to 1991. The annual population growth rate during 1991-96 is equal to 1.64 percent, and it is equal to 2.4 percent during the next decade (www.amar.org.ir). According to the census in 2011, the population of Ilam city has reached 172,213 thousand people in the form of 42,613 households, and the annual population growth during the decade has been equal to 1.44 percent. The population of Ilam in 2016 was 194,030 thousand people in the form of 53,581 households, which the annual population growth during the decade is equal to 2.41 percent. Table 1 and Figures 2 and 3 show the population statistics for the period under study. In general, the trend of increasing population changes and the population growth rate during these years has been a downward trend.

Table 1. Population and household developments in Ilam city from 1956 to 2016 (AliAkbari, 2008).

\begin{tabular}{cccccc}
\hline Year & $\begin{array}{c}\text { Number of } \\
\text { households }\end{array}$ & $\begin{array}{c}\text { Number of } \\
\text { population }\end{array}$ & Family size & \multicolumn{2}{c}{ Population growth } \\
\hline 1956 & 1366 & 8346 & $11 / 6$ & Number & $\begin{array}{c}\text { Annual } \\
\text { percentage }\end{array}$ \\
1966 & 2543 & 15493 & 6.09 & - & - \\
1976 & 5747 & 32476 & 5.65 & 7147 & 6.19 \\
1986 & 15886 & 89035 & 5.6 & 16983 & 7.4 \\
1991 & 19779 & 116428 & 5.89 & 65559 & 10.65 \\
1996 & 22732 & 126346 & 5.56 & 27393 & 3.53 \\
2006 & 34549 & 160355 & 4.49 & 9918 & 2.41 \\
2011 & 42613 & 172213 & 4.04 & 11858 & 1.44 \\
2016 & 535381 & 194030 & 3.63 & 21817 & 2.41 \\
& & Average & & & 4.34 \\
\hline
\end{tabular}




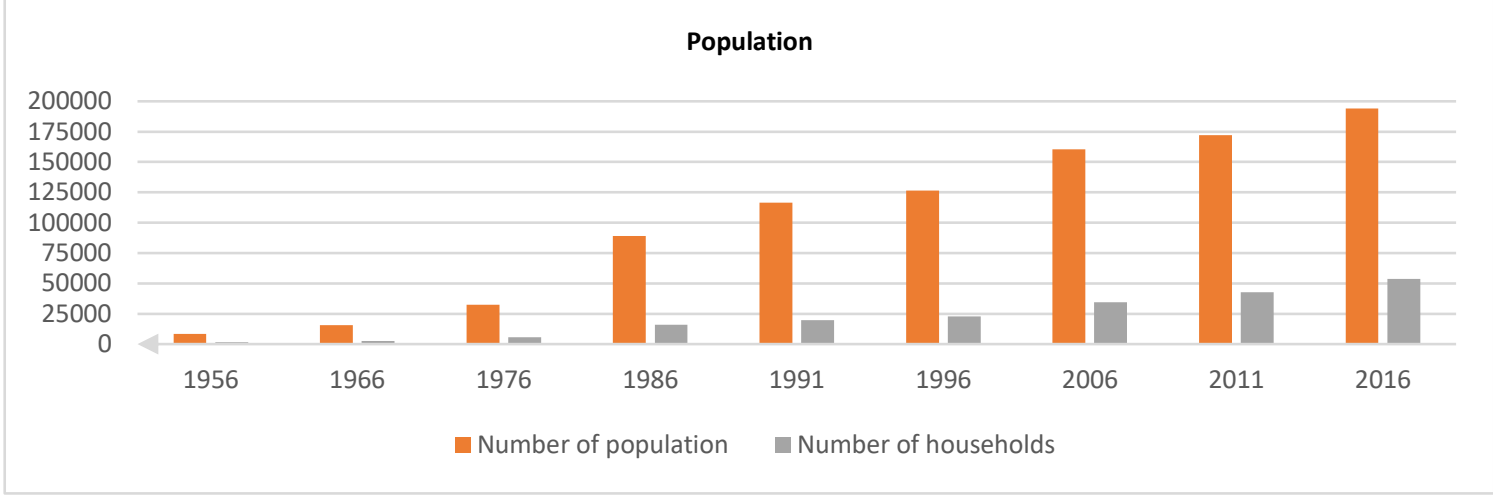

Figure 2. Population changes in Ilam city from 1956 to 2016

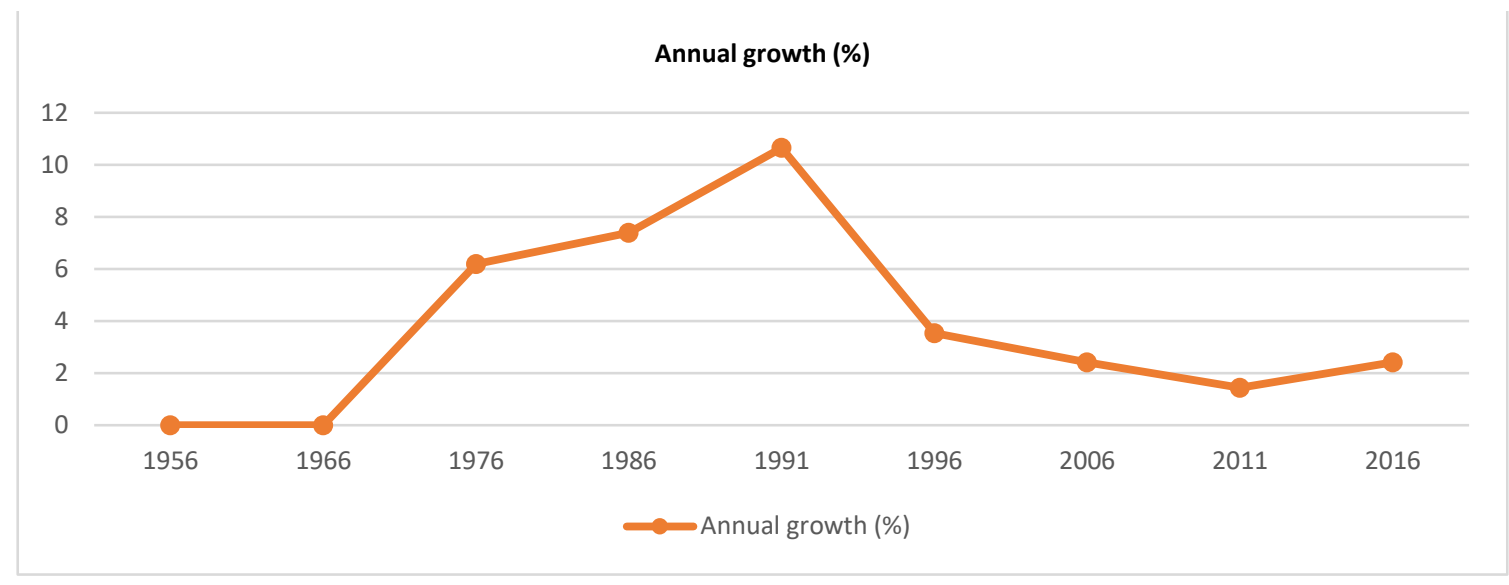

Figure 3. Annual growth (\%) changes in Ilam city from 1956 to 2016

\subsection{Population Density}

The level of services of Ilam Municipality, which is determined by the comprehensive plan and is the criterion for providing services and construction by the municipality of this city, is divided into 4 districts, 14 areas, and 38 urban neighborhoods. The density of areas was obtained from each division of population over the area. In 1996 , the total density or gross population density, which shows the population ratio to the city, was equal to 75.23 people per hectare. In 2004, it reached 83.53 people per hectare. In 2016, the population reached 194030 people, and its total density reached 160 people per hectare. According to the population growth rate from 2011 to $2016(2.41 \%)$, the population and the situation of gross density were obtained in the districts and urban areas of Ilam in the current situation. The density situation is classified into four groups as follows:

- Less than 70 people per hectare

- $\quad$ 89-70 people per hectare

- $\quad$ 160-89 people per hectare

- More than 160 people per hectare

The highest density was in Banberz and Markazi areas, which were equal to 161.43 and 149.37 people, respectively, and the lowest density was equal to 18.28 people per hectare, which is observed in the area behind the Broadcasting. Also, the highest density is in district 2 (161.43), and the lowest is in district 3 (18.28). 
Table 2. Population distribution and density in the areas of Ilam city in 2007.

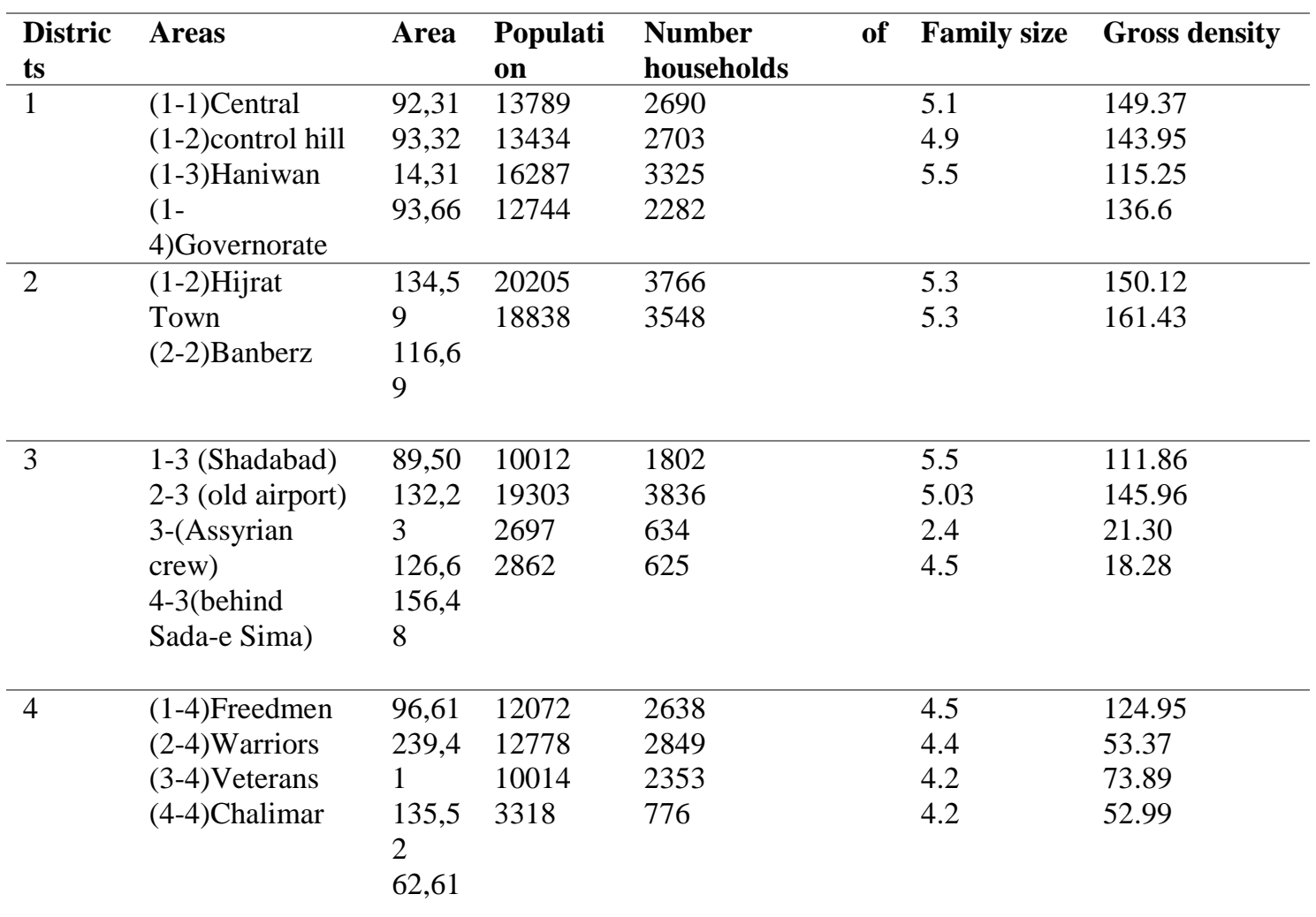

During this period, no attention was paid to the facade of the building, and all the buildings were covered with ordinary cement from the outside. The factors that caused the growth and development of Ilam in this period are various. Between 1956 and 1966, the existence of potential agricultural lands, pleasant climate, gardens, and attractive natural springs attracted the population of the surrounding villages to the city. Since 1966, the existence of the National Land Reform Law caused the small-owners residents who were deprived of the land reforms to migrate to the city, resulting in relatively high city expansion.

\subsubsection{Between 1975 and 1989}

During these years, several factors caused the physical expansion of the city. The change of Ilam from district to province and the creation of infrastructure and services has attracted the population of areas adjacent to the city. The Islamic Revolution in 1978 and the attention to the poor people inside the city and assigning free lands caused the migration of the population from villages to Ilam. After that, in 1980, the invasion of Iraq against Iran most people in the border cities of the province, such as Mehran and Dehloran, migrated to Ilam that caused the physical growth and development. The city area has expanded relatively much up to this period and separate and discontinuous developments have taken place in the entire city area in the east, west and south due to mountainous constraints. During this period, which coincides with the eight-year Iran-Iraq war, major parts of the city and its buildings were destroyed, and the reconstruction of buildings was done with the same previous plan and without any decorations.

\subsubsection{Between 1989 and 1996}

During this period, the war ended, and the construction period began, and it can be said that since 1989, Ilam has been built with a relatively developed plan. The buildings were built in a more engineering approach. Materials used include bricks, mortar, sand, and cement. However, during these programs, illegal 
constructions are abundant. From 1989 onwards, superior services such as universities, specialized hospitals, airports, etc., attracted the population to this city. In addition, the natural growth of population caused that in the period 86-96, it had the highest rate of urbanization and suddenly the urban population increased from 89 thousand in 1986 to more than 126 thousand in 1996. This increase in population caused a great demand for housing, and according to the limited area in the city, construction on hills was expanded. The city's expansion in this period is so much that is in two ways of connection and disconnection. The city expands to the southwest, where the villages around the city are connecting to the city.

\subsubsection{From 1996 to 2016}

This period is not separable from the previous period. Construction is in the same way, and in addition, steel frame buildings with block beam roofs are more common, and the facade of the building is very important. In recent years, according to the need of the housing market and severe shortage in this sector, the mass construction industry has become common, which is not in a good position in terms of structure and form (AliAkbari, 2008). In recent decades, Ilam has passed ups and downs in terms of physical development, so that its urban area in 1956 with an area of about 102 hectares reached an area of 2460 hectares in 2011.4.

\subsection{Affective factors of physical expansion}

Several factors have affected the physical development and expansion of Ilam, and the most important of them are discussed below.

\subsubsection{Political and military developments in recent decades}

In 1930, Ilam became one of the fifth provinces, i.e, Kermanshah, in the national divisions of Ilam, and in 1964, it became a governorate. It was promoted to a province in 1974. This factor led to the city's development in all dimensions, especially physically, spatially, and demographically. In addition, Ilam province has a long border with Iraq from the west. At the beginning of the war, it was attacked in this way and occupied most. During this war, several cities in the province were destroyed, and the infrastructure, educational centers, health centers, and communication facilities of the province, especially Ilam, were completely damaged. Another effect of the war on this city was its rapid and uncontrolled physical development due to the invasion of war immigrants. The destruction of $50 \%$ of Ilam city in terms of physical and general damages to economic, social, cultural, and infrastructure structures Ilam city. The invasion of migrants of imposed war from damaged and destroyed cities and villages to Ilam city and increasing the population of this city and consequently, the increase in the problems of these cities in the field of facilities, urban services, etc.

\subsubsection{Administrative-political centrality of the city}

One of the main problems of the cities of Ilam province in providing services and their functions is administrative-political density and concentration. Although density and concentration to some extent seem necessary for economics and implementation of development and welfare projects and infrastructure projects, excessive emphasis on this issue in the country and Ilam province has created many urban issues. The most important reasons for the density and administrative and financial concentration are the severe limitations of resources and budget credit, the lack of specialized and skilled manpower to implement projects in all cities and populated areas, and the lack of infrastructure and welfare facilities.

In addition, a political factor guides the process of density and centralism beyond the mentioned factors. On the other hand, this political factor caused the lack of participation of the people and officials in local, regional, provincial decisions and their indifference to these issues. Another objection to the administrative-political focus is that a central city such as Ilam, despite having the most facilities and urban facilities and specialized and skilled forces, has the greatest need and shortage in all areas. This situation is due to the uncontrolled invasion of the population (migration) to this city and the impossibility of increasing development and expansion of facilities and equipment and welfare infrastructure at the same rate as the central city's population is growing. 


\subsubsection{Migration of villagers to the city}

The uncontrolled growth of the service sector in this city is among the economic factors that attract the most immigrants to Ilam. More concentration of capital in Ilam compared to other cities in the province, lack of ancillary and agricultural-related industries in villages- rising production costs such as wages and machinery against stabilizing the price of agricultural goods and lack of necessary welfare, education, health, and medical facilities and inattention to the necessary investments in this field has been important factors in the migration of villagers to Ilam. Therefore, one of the social motivations for migrating to Ilam was the access to educational, health, and recreational facilities and the provision of social and economic services. The expansion and urban construction around the city to the agricultural lands have been a relatively continuous flow. In addition, the city's growth towards the surrounding villages and their integration over time is quite evident. Ilam has seven suburban areas developed without a specific plan and lacks urban facilities and services and recreational and welfare opportunities in proportion to population growth. Most of these areas have many shortages on steep slopes and hills around the city, including sewage canals and urban facilities (AliAkbari. 2008).

\subsubsection{The prevalence of land and housing trading and illegal construction}

The land has been assigned to most employees and even those who have owned private homes in recent decades in Ilam through the Housing and Urban Development Organization, many of whom buy and sell due to lack of need. In different districts of Ilam, this buying and selling are very noticeable, which has been one of the important factors in the physical development of Ilam. In recent years, especially at the end of the imposed war, the migration of villagers to cities has increased the population and consequently increased the price of land. Due to the migrants had no shelter. As a result, they built and constructed unauthorized in various ways that the undesirable consequences of this are the unintentional expansion of the city, environmental problems, and the destruction of agricultural lands.

\section{Conclusion}

Ilam city has changed from a village to a city and then to the province's center during the social, economic, and political changes in the last few decades. Statistics and analyzes show that the population of Ilam has increased 16 times during the 60 years from 1956 to 2016. The spatial growth and development of Ilam city are significantly affected by the 8-year Iran-Iraq war. Despite the end of the war, due to the beginning of extensive and significant civil operations and the significant role of Ilam (administrative-political and service centrality) as well as attention to deprived areas, it has continued to exogenous and induced growth. Migration from villages and small towns to Ilam affected several sections. It increases unemployment, unbalanced growth of the city, marginalization, ugliness of urban landscape, coexistence and conflict of urban and nomadic cultures, increasing social anomalies. Additionally, it led to the increasing population without urban infrastructure, has endangered the urban environment and led to the excessive use of resources and facilities.

It is necessary to consider the sustainable urban development approach proposed by the United Nations as a fundamental solution to reduce the existing problems.

Rapid population growth followed by rural-urban migration and natural growth (birth rate) and mismatch of population growth with the capacity of urban infrastructure in most urban areas is saturated, and the stability of areas in terms of sustainable urban development has become unstable. In addition, marginalization, social segregation, and finally, social inequality in the spaces of Ilam city are other factors following the unplanned expansion of the city and the mismatch of population growth with the capacity of urban infrastructure. On the other hand, urban per capita has not been taken place in the urban areas physically and appropriately. Also, conversion of agricultural lands into residential spaces and imponderable urban constructions and destruction of natural facilities and capabilities of the urban environment, the rapid growth of physical development, rupture of urban texture (empty spaces within the city). Moreover, urban landscape disorders, marginalization, social problems and anomalies including the highest suicide rate in the country, are other issues raised in the economic, social, cultural and spatial-physical dimensions of sustainable urban development. 


\section{References}

Pourmohammadi, P, Zamani, A. (2007). evaluation of spatial-physical development of Zanjan city with an emphasis on land use change in 2005-2006. University of Tehran.

Muhammed, A, Karimi, H, Gharab, B Neamat, S. Mirzaei. K. (2020). Assessment of the Quality of the Environment in Duhok Province, Kurdistan Region of Iraq. JoCEF, 1 (1), 20-24.

Kourosh Niya, A, Huang, J, Karimi, H, H. Keshtkar, H, Naimi, B. (2019) Use of Intensity Analysis to Characterize Land Use/Cover Change in the Biggest Island of Persian Gulf, Qeshm Island,

Iran. Sustainability, 11,4396. https://doi.org/10.3390/su11164396

Roostayi, Sh, Aliakbari, E , Hoseinzadeh, R (2016) Studying the Key Influencing Factors on the Growth of Large Cities (Case Study: the City of Urmia). Research and Urban Planning. 7 (26); 53- 74.

Lei, Y, Flacke, J , Nina, S (.2021) Does Urban planning affect urban growth pattern? A case study of Shenzhen, China. Land Use Policy, $101 \backslash$

Hu, D.; Yang, G.; Wu, Q.; Li, H.; Liu, X.; Niu, X.; Wang, Z.; Wang, Q. (2008) . Analyzing Land Use Changes in the Metropolitan Jilin City of Northeastern China Using Remote Sensing and GIS. Sensors , 8,5449-5465. https://doi.org/10.3390/s8095449

Bagan, H, Yamagata ,Y . (2012). Landsat analysis of urban growth: how Tokyo became the world's largest megacity during the last 40 years. Remote Sens. Environ. 127 210-22

Karimi, H, Jafarnezhad, J, Khaledi, J, Ahmadi, P, (2018). Monitoring and prediction of land use/land cover changes using CA-Markov model: a case study of Ravansar County in Iran. Arab J Geosci. 11 (592).. https://doi.org/10.1007/s12517-018-3940-5

Kourosh Niya, A, Huang, J, Kazemzadeh-Zow, A, Karimi, Naimi .H. (2020). Comparison of three hybrid models to simulate land use changes: a case study in Qeshm Island, Iran. Environ Monit Assess 192, 302.. https://doi.org/10.1007/s10661-02008274-6

Karimi, H Jafarnezhad, J, Kakhani, A, (2020) "Landsat Time-Series for Land Use Change Detection Using Support Vector Machine: Case Study of Javanrud District, Iran," 2020 International Conference on Computer Science and Software Engineering (CSASE), pp. 128-131, DOI: 10.1109/CSASE48920.2020.9142087.

Mustafa, Y,T. (2020). Multi-temporal Satellite Data for Land Use/Cover (LULC) Change Detection in Zakho, Kurdistan RegionIraq. In: Al-Quraishi ,A, Negm A. (eds) Environmental Remote Sensing and GIS in Iraq. Springer Water. Springer, Cham.. https://doi.org/10.1007/978-3-030-21344-2_7

Alawamy J.S,; Balasundram ,S.K,; Mohd,A.H, Hanif, Boon Sung, C.T. (2020). Detecting and Analyzing Land Use and Land Cover Changes in the Region of Al-Jabal Al-Akhdar, Libya Using Time-Series Landsat Data from 1985 to 2017. Sustainability, 12,4490. https://doi.org/10.3390/su12114490

Effati, F, Karimi, H, Yavari, A. (2020). Investigating effects of land use and land cover patterns on land surface temperature using landscape metrics in the city of Tehran, Iran. Arab J Geosci. 14, 1240.. https://doi.org/10.1007/s12517-021-07433-4

Ilam Governor's Office, (2010). Office of National Divisions.

Iranian Annually Statistical. 2001. www.amar.org.ir

Musa Kazemi, S. (2007).Sustainability assessment of urban development, concepts and methods and indicators, Peyk Noor, Payame Noor University Quarterly, Fifth Year, Second Issue.

Statistics Center of Iran. 2016. www.amar.org.ir

AliAkbari, S. (2008). Analysis of the green space of Ilam with the effect of sustainable development, Master Thesis, Payame Noor University, Central Tehran. 